\title{
Editorial: Understanding Hydrological Extremes and Their Impact in a Changing Climate: Observations, Modeling and Attribution
}

\author{
Xingcai Liu ${ }^{1 \star}$, Zhe $\mathrm{Li}^{2}$ and Pedram Attarod ${ }^{3}$ \\ ${ }^{1}$ Institute of Geographic Sciences and Natural Resources Research, Chinese Academy of Sciences, Beijing, China, ${ }^{2}$ Department \\ of Civil and Environmental Engineering, University of Wisconsin-Madison, Madison, WI, United States, ${ }^{3}$ Department of Forestry \\ and Forest Economics, Faculty of Natural Resources, College of Agriculture and Natural Resources, University of Tehran, \\ Karaj, Iran
}

Keywords: hydrological extremes, climate change, detection and attribution, models, drought index, human activities

Editorial on the Research Article

Understanding Hydrological Extremes and their Impact in a Changing Climate: Observations, Modeling and Attribution

The hydrological regimes have been significantly altered by climate change and human activities, which have resulted in increased hydrological extreme events such as floods and drought over the world (Samaniego et al., 2018) and it seems likely this trend will continue in the future (Liu et al.,

OPEN ACCESS

Edited and reviewed by: Nick Van De Giesen, Delft University of Technology, Netherlands

*Correspondence: Xingcai Liu

xingcailiu@igsnrr.ac.cn

Specialty section:

This article was submitted to Hydrosphere a section of the journal

Frontiers in Earth Science

Received: 22 November 2020 Accepted: 27 November 2020 Published: 18 February 2021

Citation:

Liu X, Li Z and Attarod P (2021) Editorial: Understanding Hydrological

Extremes and Their Impact in a Changing Climate: Observations,

Modeling and Attribution.

Front. Earth Sci. 8:632186.

doi: $10.3389 /$ feart.2020.632186 2019a). Better understanding and forecast of hydroclimatic extremes are required for mitigating the impacts of the extreme events in the context of global warming. This calls for in-depth investigations on evolution and mechanism of hydroclimatic extremes. So far, the assessment and attribution of the hydrological extremes and their impacts on the regional/global scales remain a great challenge (Schewe et al., 2019). Hydrological models are powerful and physically-based tools for the assessment of hydrological extremes, while the statistical indices are efficient and data-driven approaches based on hydroclimatic observations for identifying and assessing flood and drought events. This special issue focuses on the development and application of various model- and index-based techniques for the detection and attribution of the changes in hydroclimatic extremes induced by climate change and human activities.

To understand the uncertainty in the widely used Standardized Precipitation Index (SPI), Zhang and $\mathrm{Li}$ (2020) investigated the effects of probability distributions and parameter errors on the estimates of SPI in the Heihe River basin, northwest China. Ten probability distributions were tested and the SPI using log-logistic-type distribution produced similar results as the benchmark SPI using the gamma distribution. As one of the most sensitive regions to climate change, the assessment and attribution of the changes in water resources in the Yarlung Zangbo river have attracted much attention of hydrologists during the 21st century (Yao et al., 2010; Tang et al., 2019). Niu et al. (2020) evaluated the drought characteristics in the Yarlung Zangbo River basin from a different perspective by using SPI, Soil Water Deficit Index (SWDI), and self-calibrating Palmer Drought Severity Index (PDSI) based on the output from Global Land Data Assimilation System and the Climate Research Unit dataset. The three indices indicated that drought conditions have aggregated to different degrees over the basin. The increased drought may be partly due to climate change in this basin (Lutz et al., 2014), however, the attribution of the changes in hydroclimatic extremes remains subject to large 
uncertainty because of human interventions and the lack of highquality observations in such mountainous river basins.

The regional extremes are often not merely caused by the hydroclimatic variations on the local scale. Hamal et al. (2020) pointed out that dry and wet conditions over the Tibetan Plateau and surrounding areas might be significantly associated with large-scale circulations, e.g., the cyclonic and anticyclonic circulation in northern India. They showed that surface air temperature over these regions was colder in wet years than dry years. Further investigation on the relations linking dry/wet conditions, large-scale circulations, and heat extremes would definitely benefit the forecasts of regional extreme weather (Liu et al., 2019b).

Human activities would often aggregate hydroclimatic extremes under climate change, which can be better represented via hydrological models. By developing a water resources allocation model, Zeng et al. (2020) showed that water deficit would be largely mitigated along the east route of the South-to-North Water Transfer Project in Jiangsu Province, China. Based on remote sensing data, Song et al. (2020) pointed out that the coastal wetland has shrunk substantially during the past four decades mainly due to seaward shifting caused by human interventions such as intensive land reclamation. Intertidal wetland conservation should be a high priority over this region because the sea level was projected to rise more than 0 .

\section{REFERENCES}

Liu, X., Tang, Q., Liu, W., Veldkamp, T. I. E., Boulange, J., Liu, J., et al. (2019a). A spatially explicit assessment of growing water stress in China from the past to the future. Earths Future 7, 1027-1043. doi:10.1029/ 2019 ef001181

Liu, X., Tang, Q., Liu, W., Yang, H., Groisman, P. Y., Leng, G., et al. (2019b). The asymmetric impact of abundant preceding rainfall on heat stress in low latitudes. Environ. Res. Lett. 14, 044010. doi:10.1088/1748-9326/ab018a

Lutz, A. F., Immerzeel, W. W., Shrestha, A. B., and Bierkens, M. F. P. (2014). Consistent increase in High Asia's runoff due to increasing glacier melt and precipitation. Nature Clim. Change 4, 587-592. doi:10.1038/ nclimate 2237

Qu, Y., Jevrejeva, S., Jackson, L. P., and Moore, J. C. (2019). Coastal Sea level rise around the China Seas. Global Planet. Change 172, 454-463. doi:10.1016/j. gloplacha.2018.11.005

Samaniego, L., Thober, S., Kumar, R., Wanders, N., Rakovec, O., Pan, M., et al. (2018). Anthropogenic warming exacerbates European soil moisture droughts. Nat. Clim. Change 8, 421-426. doi:10.1038/s41558-018-0138-5
$5 \mathrm{~m}$ around China seas in the future due to global warming $(\mathrm{Qu}$ et al., 2019). In the research report of Xiao and Li (2020), a simulation of the downward groundwater leakage rate based on the MODFLOW model was conducted to examine the risk of sinkhole hazards induced by human activities. Hydroclimatic extremes can have further impacts on water resources. Dang et al. (2020) reported that the intensification of extreme precipitation would significantly increase sediment yield in many branches of the Yellow River based on a scenario analysis, which may cause deterioration of the water environment in the Yellow River basin.

\section{AUTHOR CONTRIBUTIONS}

XL wrote the draft of the manuscript, ZL and PA editted and commented on the draft. All authors approved the manuscript for publication.

\section{ACKNOWLEDGMENTS}

We thank all the reviewers for reviewing the papers in the special issue. This research was funded by the National Natural Science Foundation of China (No. 41877164).

Schewe, J., Gosling, S. N., Reyer, C., Zhao, F., Ciais, P., Elliott, J., et al. (2019). Stateof-the-art global models underestimate impacts from climate extremes. Nat. Commun. 10, 1005. doi:10.1038/s41467-019-08745-6

Tang, Q., Lan, C., Su, F., Liu, X., Sun, H., Ding, J., et al. (2019). Streamflow change on the Qinghai-Tibet Plateau and its impacts. Chin. Sci. Bull., 64, 2807-2821. doi:10.1360/TB-2019-0141

Yao, T., Li, Z., Yang, W., Guo, X., Zhu, L., Kang, S., et al. (2010). Glacial distribution and mass balance in the Yarlung Zangbo River and its influence on lakes. Chin. Sci. Bull. 55 (20), 2072-2078. doi:10.1007/s11434-010-3213-5

Conflict of Interest: The authors declare that the research was conducted in the absence of any commercial or financial relationships that could be construed as a potential conflict of interest.

Copyright (c) $2021 \mathrm{Liu}, \mathrm{Li}$ and Attarod. This is an open-access article distributed under the terms of the Creative Commons Attribution License (CC BY). The use, distribution or reproduction in other forums is permitted, provided the original author(s) and the copyright owner(s) are credited and that the original publication in this journal is cited, in accordance with accepted academic practice. No use, distribution or reproduction is permitted which does not comply with these terms. 